\title{
Practice of adoption in Aotearoa before the 1881 Adoption of Children Act
}

\author{
Erica Newman (Māori descent, Iwi unknown), University of Otago, Aotearoa New Zealand
}

\begin{abstract}
INTRODUCTION: With the arrival of Europeans in Aotearoa New Zealand came a familial kinship structure and ideas of caring and nurturing children different from that of indigenous Māori society. Europeans brought with them a practice of adoption, a concept that differed from the indigenous kinship practice of whāngai. This led to misunderstandings between the two cultures about care arrangements, particularly when a Māori child was left with a European couple. Even the reasons why Māori engaged in this type of arrangement was often not fully understood by Europeans. For Māori, these arrangements were usually temporary, while Europeans considered them to be permanent. Hence, we have the beginning of the challenges that contributed to the creation of the 1881 Adoption of Infants Act, a first within the British Empire.

APPROACH: This article begins with a description of the Māori practice of whāngai and the European practice of adoption preceding the 1881 act, highlighting the key differences between each-the most significant difference being the European idea of permanent and the Māori idea of temporary care arrangements.
\end{abstract}

KEYWORDS: Adoption; whāngai; kinship; Māori; European
The purpose of this article is to discuss the practices of adoption in Aotearoa New Zealand before the enactment of the first Adoption of Children Act in 1881 and its intersection with parallel Māori practices of the 19th century. This article begins with a description of the Māori practice of whāngai and the European practice of adoption preceding the 1881 act, highlighting the key differences between them - the most significant of which were the European idea of permanent and the Māori idea of temporary care arrangements. Finally, we follow how initiatives led by the government of Aotearoa New Zealand resulted in the legal, permanent care arrangements for children by initiating the 1881 Adoption of Infants Act.

\section{Whāngai}

Whāngai is the Māori kinship method of child circulation where a child may move, or be moved, from one familial household to another for a specific reason, sometimes temporary and sometimes permanently (Newman, 2011). The practice of whāngai within Māori society, even with Crown intervention, is still evident today. The word "whāngai," means "to feed" but in the context of a child, a tamaiti whāngai:

... focused not only upon food but also upon nurturing, educating, providing opportunities to grow up as a healthy individual with one's mauri strong, one's mana secure and one's tapu intact.

(Mead, 1997, p. 209)

Atawhai is another concept that is often interpreted as adoption and is defined as meaning to show kindness or to foster (Williams, 1992). However, neither whāngai or atawhai are equivalent to the English term
AOTEAROA

NEW ZEALAND SOCIAL WORK 32(3), 43-53.

CORRESPONDENCE TO: Erica Newman

erica.newman@otago.ac.nz 
"adoption." A child within Māori society was deemed to be a taonga (treasure) of the entire whānau (family) (Bradley, 1997; S. Walker, 2001). Decisions on where a child should live and with whom were not taken lightly. Initial discussions were usually held between the two parties (parents with possible atawhai / whāngai parents) and mediated with a kaumātua or sometimes a meeting with all members of the whānau, ensuring that the right decision was made for the child and whānau (Metge, 1995). Metge does note that approval by all whānau was valued but not always essential, especially if the child was already a member of the whānau (Metge, 1995). If the child was whāngai there was no legal transfer from one set of parents to the other and it was never presumed that this care arrangement would be permanent. Importantly, the tamaiti whāngai retained all knowledge in regard to their history, their place within the community, spiritual values, and genealogical links (Bradley, 1997). Tamaiti whāngai were usually cared for by relatives, depending on the circumstances and reasons for this arrangement (Papakura, 1986). Individual parents did not have the right to place children into another culture or with strangers, as this was believed to be an act of cultural violence that was avoidable if the child stayed within their own whānau (Aginsky \& Buck, 1940; Mead, 1997;

S. Walker, 2001).

The concept of whakapapa (genealogy), the connection to the ancestors is an essential element for Māori identity and for the spiritual wellbeing of Māori (Te Rito, 2007). It is within whakapapa that the history of a lineage is taught. Whakapapa is not just a chart that provides names of ancestors with links to relatives, it also exists as a genealogical narrative that is inclusive of each ancestor (Te Rito, 2007). For children to develop their identity they need to be nurtured, to gain knowledge of who they are, where they belong, and to be able to reciprocate the care that they have received; a difficult task to undertake without the knowledge of whakapapa (Newman, 2011).
There were, and are, a number of reasons for a child to become whāngai. These include the death of one or both parents, to help relatives who were struggling to conceive, or if there were problems in the home such as the illness of parents. Often the first born grandchild would be raised by the grandparents and this is still practised by some whānau today. This provided the grandparents the opportunity to transfer traditional knowledge to their grandchild (Metge, 1995).

The essence of whāngai is to focus on the welfare of the child and the community at large. A primary concern in the arrangement of whāngai is that the child retains their identity, and has the knowledge of where they come from and who they are descended from. Not only is this significant for the child's own identity but also for retaining their rights to land succession (Graham, 1948 , p. 268). For Māori, this form of care arrangement of children was essential as they believed in "keeping the children in the family, because if a stranger became the parent of the children, the children would drift away from the family" (Aginsky \& Buck 1940, pp. 208-209).

Relatives had a responsibility to ensure whakapapa was retained and taught to the child in order to provide them with a strong identity. Whāngai was a normal kinship practice within the Māori kinship structure where the tamaiti whāngai usually continued their relationship with their biological parents. Whāngai was not seen as an anomaly or a disadvantage to the child, parents, relatives or community, it was simply a kinship practice that did not alter who the child was, where they came from or what their role was within the whānau. With the advent of colonisation, the $1852 \mathrm{New}$ Zealand Constitution Act recognised the status of tamariki whāngai as part of the:

... laws, customs and usages of the Aboriginal or Native Inhabitants of New Zealand, so far as they are not repugnant to the general principles of humanity, 
should for the present be maintained for the government of themselves, in all their relations to and dealings with each other, and that particular Districts should be set apart with which such laws, customs or usages should be so observed. (pp. 18-19).

As such, tamariki whāngai was an acceptable custom, at least until 1910 (Griffith, 1997).

\section{European adoption}

The European settlement of New Zealand, since 1840, introduced a different concept of family and societal structure. These new settlers stressed a more individualistic view rather than a collective one; they lived as individuals or within a nuclear family. European family structures within European society were generally paternalistic with the husband / father being the head of the family and the breadwinner, while the wife maintained the household and cared for the children (Mikaere, 1994). The use of institutional care such as orphanages, poor houses and workhouses to care for the orphaned, neglected and destitute was well understood within these European households (Tennant, 2007). But this was all quite foreign for Māori.

Early European writers have described traditional processes of adoption in Māori society and, although these writings contain valuable information, they are written from the perspective of their own preferred cultural ideals and practices. For example, when the concept of whāngai was discussed it was compared to the English term "adopt," which the Oxford Dictionary defines as to "legally take (another's child) and bring it up as one's own" (Soanes \& Stevenson, 2008, p. 17). This is similar to the explanation within the original 1881 Adoption of Children Act which defines the effect of the adoption as:

When such order [adoption] has been made, the adopted child shall, for all purposes, civil and criminal, and all advantages and benefits and other legal consequences of the natural relation of parent and child be deemed in law to be the child born in lawful wedlock of its adopting parent. (1881, p. 49)

This continued with the passing of the 1955 Adoption Act and is current within the 2020 reprint with the wording on the effect of adoption stating:

The adopted child shall be deemed to become the child of the adoptive parent, and the adoptive parent shall be deemed to become the parent of the child, as if the child had been born to that parent in lawful wedlock. (1955, pp. 1141-1142; 2020, p. 18).

As with most colonial settlements, Europeans had a keen interest in understanding traditional practices of what they understood to be adoption in order to understand who had rights to land. From a European perspective, when a child was adopted, for all intents and purposes they now belonged entirely to their new family.

\section{Informal European adoption}

Before 1881, it was common for European couples, in general, to care for children who were not their own; this might have been a child given to them by the parents for any number of reasons. This was seen as an informal adoption, a system of caring for children that European settlers had practised in their home country. The issue of informality created insecurity for the adoptive parents with the possibility of parents returning to claim their child. Some adoptive parents wrote up contracts between themselves and the birth parents regarding the custody of the childhowever, these held no legal value. If the biological parents returned to claim their child, in most circumstances the courts could not intervene. Court intervention only occurred if a child was being mistreated and the birth parents were behaving in a manner that was detrimental to the child (Gillard-Glass \& England, 2002). 
This was not the only issue that arose from early, informal adoptions. Another significant issue related to inheritance, especially land succession for Māori. A child who was part of an informal adoption was not entitled to inherit from either their birth or adoptive parents as there was no legal transfer of children at this time (Adoption of Children Bill, 1881).

So how did these two ideas of family, in particular the practice of moving children between households, fit in Aotearoa New Zealand society before the advent of formal legal practices of adoption? Europeans believed that if Māori were to survive, or at least not become extinct altogether, then some Māori children should be raised within a European family. As the following quote shows, for some, this was a way in which to save a decaying race. Where only by growing up within a European household and cared for by European women could a child flourish and a race be saved, assimilated in the ideas and morals of the "civilized" Europeans.

It is only necessary to look at a young Maori child which has been brought up in the house of a European and has been looked after by a European woman to see the beneficial effect which cleanliness, ease, and good food, would have on the whole New Zealand Race. The puny limbs of the young savage grow stout, the protuberant belly disappears, the languishing eye becomes bright, the face chubby and the complexion so clear that you can trace the blush of its red blood through its olive coloured skin. (New Zealand Spectator and Cook Strait Guardian 1852, p. 2).

Building relationships or whakawhanaungatanga between Māori and their European neighbours would highlight how tikanga practices could be used within both worlds. There was no reason why those relationships would not extend to temporary whāngai practices in both directions, remembering that Māori would share their children with family or at least with people they know. The issue here is that Europeans might still see this as a permanent, nonintrusive arrangement whereas Māori might not.

There are few cases before 1881 of Pākehā adoption of Māori children. Sometimes informal adoption resulted from the abduction of a child, especially during the New Zealand Land Wars, when children were taken by force from one society and raised in another, a concept contrary to the practice of whāngai. For example in 1868 at Te Ngutu o te Manu, William Fox abducted a seven-year-old Māori boy named Ngatau Omahuru after attacking the village of the child's parents. In January 1869, Fox had Ngatau baptized and named after himself. Although Fox never intended to adopt this child, his actions resulted in an informal transracial adoption. On the child's baptismal certificate his new name replaced his birth name; however, his biological parents remained recorded as his parents. Fox had the child sent to Wellington to receive a Pākehā education and it was not long before the boy became assimilated into Pākehā society (P. Walker, 2001) and became one of New Zealand's most notable informal transracial adoptions.

Records in newspapers of this practice between the two cultures were more sensational when Māori were caring for European babies. For instance, this example from Wanganui Herald in 1877 of a European father who sold his daughter to a Māori couple, which appears to have resulted in the best interests of the child.

A curious story comes from the Hutt. A certain laborer resident in that locality actually sold his own daughter, a little girl of five years of age, to a Maori for the sum of $£ 2$ sterling. The purchaser is married, but has no family, and bought this little girl to adopt and bring up as his own child. The poor child fared ill, and was much neglected by her natural (rather unnatural) parent. She is most 
kindly treated by her adopted father. (Wanganui Herald, 1877, p. 2).

Another example includes the reporting, in 1869, in Makara, of a white child seen to be living with a white man and a Māori woman, deprived, malnourished and uncared for. The child is reported to be living amongst the Māori and that he was originally from the Waiarapa. There was great discussion about how his Māori guardians ill-treated the child and how the locals, white locals, provided the child with as much pastoral care as they could. The report finishes with not wanting to publish any names "until the matter is brought before the public in the ordinary way" (Wellington Independent, 1869, p.2).

Although the following examples are dated after the 1881 Adoption Act was enacted, they provide further evidence that adoption took place between Māori and Pākehā. On 25 November 1882, the New Zealand Mail reported a case where a white girl, Annie Freebody aged nine, had "been living under the care of a Māori named Winiata in the Wairarapa district" (p. 22). Mr Justice Richmond ordered Winiata to surrender the child to him as she was to be returned to her relatives. One can only assume that an agreement had been made between the parents or at least one parent for the child to have been placed into Winiata's care. With the 1881 Adoption of Children Act now in force, it would appear that the relatives of the child requested Annie to be returned.

What was seen to be a "a special feature of public interest" was where a "Maori chief" sought permission to adopt a European child at the regular meeting of the Hospital and Charitable Aid Board held on the evening of 9 April 1888, published in the New Zealand Herald on 10 April 1888, page 4. This same case was also published on 11 April 1888 in the Otago Daily Times. In this article, the Māori chief was named as Te Whakarata from Waitangi and he had the support of the Reverand H. Lawry and Reverend Mr Gittos. A following article in the Otago Witness had yet more information identifying the European child as a female.

Another case was reported on 5 April 1889 by the Daily Telegraph that a white child, illegitmate, was living with Pomare at the Tapairu pā. The child's name was Coleman. According to the Māori who were raising Coleman they had adopted the child. However, the reporter believed this to be nonsense as Māori could not adopt a non-Māori child (which is interesting as this did not come into law until the Native Land Act of 1910, but it shows that the rules were changing before legislation went through). The reporter concluded that the child was being ill-treated and that the child had been deserted therefore had become a "white slave." The reporter concluded that Coleman should be "charged as a neglected child, removed from the deleterious atmosphere in which he is at present" and once his parents were found, they should maintain him at the industrial school. The reporter finishes with "at present his only school is the pah gutter" (p.3).

Each of these articles provide a glimpse that Māori were taking care of European children but these only appear to be reported when there was an issue or when it was perceived as an anomaly. Other instances of Māori taking care of European children must have occurred based on the fact that the Native Land Amendment Act in 1910 put a stop to Māori taking in European children, by this time legally adopting them.

\section{Half-castes "Euronesians"}

In 1843 there is an infamous newspaper article written by G. W. Hope, titled “The Euronesians, or the children of European and Native Parents." This article discussed the rights of half-caste children which he defines by stating "we allude to the descendants of European fathers and Maorie mothers, commonly called "half casts" (Daily Southern Cross 1843, p. 2). And describes these children as "the children of misfortune, and as such, are too often 
neglected and despised" (Hope, 1843, p. 2). An assumption was made that children who were deemed to have been born under reputable circumstances and within English law, i.e., a legal marriage between the European father and Māori mother, surely would be able, under English law, "to inherit the properties of their English fathers, and according to native custom, and to the treaty of Waitangi, they are entitled to all the rights and privileges of their native ancestors" (Hope, 1843, p. 2). Although in theory this would seem plausible, at this point it appears that there had not been any legislation passed that made this practice legal. Hope describes the case of a Mr Maxwell who was married to a native woman and had a number of children. Maxwell was the proud owner of a considerable amount of land which he had purchased from Māori before the government of New Zealand was established. He had provided his children with a quality European education but Maxwell died, drowned, while his children were still young,

... his lands are unclaimed, unoccupied and useless to his family, from comfort and civilization his children have been reduced to want and to barbarism itself. His young sons whom he endeavoured to educate and to bring up as civilized beings, are now living with the natives almost naked, and dependent on their bounty for their bread. Their father's property has been by this Government rendered valueless, their right to it is denied, and they will themselves become savages and heathens. They have no protector, no one to look after their interests, or that of their parent and her other children. Neither the Church nor the State have become their guardians: on the contrary, the Government and the Commissioners of Land Claims have thrown every obstacle in their way. (Hope, 1843, p. 2).

The purpose of the article was to make the government of the time provide rights and privileges for the Euronesian children of
Aotearoa New Zealand-from both their European and Māori parents. The article finishes with the suggestion:

We sincerely trust that these remarks may be read by some of the benevolent, charitable and religious people at home, and that some effort will be made by them in behalf of this unfortunate class of persons. It would be well to appoint protectors and to establish an institution in this country for the maintenance and education of such persons. Let not our friends at home however expect any assistance from Government or from religious sects in this country. The case we have mentioned above is known to the Government, and ought to be known to the ministers of religion, and yet nothing but the destruction of the valuable property of these unfortunate orphans has been accomplished. Charity, justice and mercy seldom find their way into the British Colonies, and if they do, they soon expire. (Hope, 1843, p. 2).

It is interesting that, rather than focus on the rights of inheritance for the children, it was considered that it would be in their best interest to be institutionalised so that they would avoid living within te ao Māori and remain within European "civilisation." This is one example of how Europeans perceived half-caste children and provides evidence that those with European blood were seen as even more deserving of a civilised life. With the number of half-caste children rising around the country, some thought it was necessary to intervene in order to rescue them from an uncivilised life.

The idea of intervening to rescue half-caste children is evident within early legislation as, only three years later, 1846, Governor Grey introduced an Ordinance for the Support of Destitute families and illegitimate Children. Grey's intention for this ordinance is described as "a first step towards preventing destitution in the Colony" (New Zealander 1846, p. 3). The targets were "mainly wifedeserters and fathers of illegitimate children" 
(Tennant, 2007, p. 29). It appears it had a focus (as it is written within the Legislative debates) towards half-caste children where children born to European fathers would benefit from being placed within a European family and the father would benefit by avoiding any additional charges for maintenance.

Clause 8: In every case where the order of the putative father shall be made in favour of the Half-caste child, or in favour of any other person of the Native race, it shall be lawful for such Justices to make an order on the putative father for the payment of an additional sum to be applied at such times and in such manner as they may direct to the education of such child in the English language and in the duties of the Christian religion: Provided always that the sum to be paid as last aforesaid shall in no case exceed one-fourth of the sum to be paid as aforesaid for the support of the child, nor the whole sum to be paid as hereinafter provided, in composition for such sum: Provided also that when and so soon as any such child shall by order of such Justices be committed to the custody of any person of the European race, such additional sum shall cease to be paid. (Ordinance for the Support of Destitute Families and Illegitimate Children, 1846).

The concerns that were expressed in Hope's article appear to be partially addressed when Boarding Schools for the Education of Native Children attached to Church Mission Stations opened. In 1849 such a school opened in Otawhao, Waikato for the "offspring of European fathers and Native mothers" (New Zealander, 1849, p. 2). Stating that "the large and increasing number of children of this class imperatively requires that some provision should be made for their Education" (New Zealander, 1849, p. 2).

\section{Advertising of children}

The advertising of children was not uncommon (and not illegal) until the 1955
Adoption Act. I have not come across any advertisements that state whether the child is European, Māori or half-caste-just advertisements either wanting to adopt a child or a child being available for adoption, even though there still was no adoption of infants legislation before 1881 .

Fostering still held a lot of value in the care of neglected or orphaned children and it can be assumed that this was the first option when a child was in need of care, before placing them in institutional care.

As stated, the advertising of children continued until the 1955 Adoption of Infants Act and was not uncommon nor illegal. The following are a few examples:

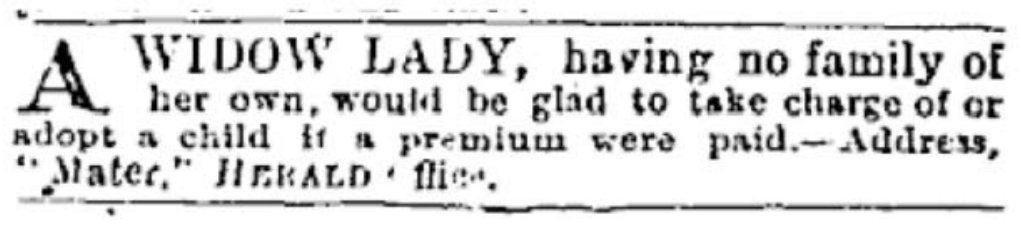

Figure 1. Wanted Advertisements. New Zealand Herald, Volume XV, Issue 5316, 29 November 1878.

\section{W ANTED, Paesper:table Person to adopt a Child (girl) nirie months old. For par- tieulars, apply IIrs Wilson, Castle street.}

Figure 2. Wanted. Evening Star (Dunedin) Issue 3712, 15 January 1875.

\section{W AN IED, a respectable Person to Adopt a Lying-in Ward, Hospital.}

Figure 3. Late Advertisements. Evening Star (Dunedin) Issue 5007, 21 March 1879.

None of these advertisements show any preference stipulated when a person advertised to adopt a child.

\section{Institutional care}

Colonial charity work first targeted women and children with the first voluntary institutions being: the early church industrial 
schools, later orphanages, along with refuges for fallen women which appeared in 1864 (Tennant, 2007). The church orphanages were the start of institutional care and they were believed to be the easiest and best way to instil moral and spiritual values in children.

In 1867, an act to Provide for the Care and Custody of Neglected and Criminal Children stated that "any Province in New Zealand to establish for the purposes of this Act industrial schools and every such school shall be occupied by and used for males or females exclusively." This act also established reformatory schools. In the understanding as to who was neglected, the act provided these definitions:

13. Every child who answers to any of the descriptions hereinafter what children to be mentioned shall be deemed to be a "neglected child" within the deemed "neglected." meaning and for the purposes of this Act

(1.) Any child found begging or receiving alms or being in any street or public place for the purpose of begging or receiving alms.

(2.) Any child who shall be found wandering about or frequenting any street thoroughfare tavern or place of public resort or sleeping in the open air and who shall not have any home or settled place of abode or any visible means of subsistence.

(3.) Any child who shall reside in any brothel or associate or dwell with any person known or reputed to be a thief prostitute or habitual drunkard or with any person convicted of vagrancy under any Act or Ordinance now or hereafter to be in force.

(4.) Any child who having committed an offence punishable by imprisonment or some less punishment ought nevertheless in the opinion of two justices regard being had to his age and the circumstances of his case to be sent to an industrial school.

(5.) Any child whose parent represents that he is unable to control such child and that he wishes him to be sent to an industrial school and gives security to the satisfaction of two justices before whom such child may be brought for payment of the maintenance of such child in such school.

Figure 4. Excerpt from An Act to provide for the Care and Custody of Neglected and Criminal Children, 1867 (p. 167).

No longer were the parents the sole carers of children, the Crown now took an active role, especially in deciding who was, and was not, fit to be a parent.

These children were sent to an industrial school to either be maintained or reformed. Part of the care arrangement in the industrial schools was the licensing-out of children in domestic service. In such a case the child must have been of sufficient age and strength, and of fair education. The contracting party had to pay reasonable wages, and provide sufficiently for clothing, board and lodging. The wages were paid to the master of the school, who placed the amount as received in the Post Office Savings Bank to the credit of the person who had earned them. It is understood that all such earnings, with the accumulated interest, would be paid to the young people once they reached adulthood or marry, good conduct being in every case a condition of payment (see The Neglected and Criminal Children Act, 1867, p. 5; Amendment to The Neglected and Criminal Children Act, 1870, p. 96; 1880 Report on Education: Industrial Schools and Orphanages (Papers Relating To) 1881, p. 4).

It was not unusual in the 19th century for a married couple without children of their own to apply for a young orphan with a view to his or her adoption. Of course, there still were no adoption laws at this time so, in these cases, the children were licensedout to the party under the terms of the act, and, if the child should be improperly treated, or if the party's conduct should prove unsatisfactory, the child would be recalled to the school. The licensing-out of children was only intended to be for a specific time period which was initially three years (see The Neglected and Criminal Children Act, 1867; 1880 Report on Education: Industrial Schools and Orphanages (Papers Relating To) 1881).

In 1869 , under the provisions of the Neglected and Criminal Children Act, 1867, the Caversham Industrial school was established and it was seen as one of the best managed schools in Aotearoa New Zealand and used as a model for others. In a report on Industrial Schools and Orphanages it was stated that, in the first year of Caversham being opened, the children admitted had been taken from brothels, and their parents described by the police as being of the lowest class. The school believed its purpose was "rescuing boys and girls from the paths of vice and infamy, and providing them with such a training as would fit them to become useful members of society" under 
the guidance of the master and matron who made strict rules and boundaries for the children to live by (see the 1880 Report on Education: Industrial Schools and Orphanages (Papers Relating To) 1881, p. 4).

However, the school came under scrutiny in 1880 when the school was, amongst other issues, alleged to have had six boys and 19 girls adopted out when there was no legal adoption of children legislation at the time. One of the main concerns was that the school's practice of "adoption" was perceived by a number of people in authority to be a legal practice of slavery. Under the investigation, however, it appears that in this instance the word "adopt" was used instead of "license-out," as stated in the report:

... we found that, although in the return of children alluded to the word 'adopted' is used, that word is only meant to express that the child was licensed-out, the warrant in both cases being precisely the same. We took exception to the word "adopted" being used, inasmuch as it has no existence in the Act, and only tended to mislead. The master, seeing the force of our objection, promised in future the word should not be used. As regards the remark that some of the girls had been licensed to "single men apparently," we found that in every instance the whole of the children had been licensed-out to married men, with one exception, that exception being the case of Mary $\mathrm{T}$ to the Rev. Father Crowley, a Roman Catholic priest at Lawrence. This girl was licensed-out two years ago, her age then being ten years. (Caversham Industrial School: (Report of Commission Appointed To Inquire into the Working and Management of) 1880 , p. 2).

Throughout this period, the word "adopt" had been used either in advertisements or as it had in the allegation made here. The Crown had issues with the idea of adoption and was worried that it could be synonymous with the practice of slavery. When the adoption of children bill did actually make it to parliament, this was a major cause for concern and debate in parliament.

\section{The 1881 Adoption of Children Act}

The introduction of the Adoption of Children Act in 1881 was designed to alleviate the issues of birth parents reclaiming their children, and to give the child inheritance rights as a full and legal member of the new household. George Waterhouse, New Zealand Premier at the time, introduced the Adoption of Children Act as a Private Members Bill. This resulted in New Zealand becoming the first country in the British Empire to have a legal form of adoption (Else, 1991). The bill was promoted as making permanent the care of a child or children in a family prepared to take on the responsibility as if the child had been born to them. Anne Else explains that Waterhouse's intentions were:

... designed to ensure that people who were willing to go to the expense and trouble of taking in and rearing other people's children would have the same status, rights and rewards as other parents, and in particular would be protected from 'disturbance' by the original parents. (1991, p. x).

Concerns were raised when Waterhouse introduced this bill. While many believed it was introduced with good intentions, amendments needed to be made before the bill could be passed. A number of concerns were raised including the age of the child, eligibility to adopt, protection of the child against use for the purpose of slavery, and from situations where someone intended to form an intimate relationship with an adopted child once it was older (New Zealand Parliamentary Debates (NZPD), 1881). One member was concerned that Waterhouse's underlying objective was to legitimise illegitimate children. This would affect "the marriage law, the law of legitimacy and the law of succession which at present existed in the colony, and he did 
not think that those laws should be dealt with in such a Bill as this one" (NZPD, 1881, pp. 131-132). Not all members agreed with this view, but amendments were made and on 18 September 1881, after the third reading in the House of Representatives, the Adoption of Children Bill was passed (NZPD, 1881).

Keeping the birth parent(s) a secret from an adopted child was not a concern for the 1881 Adoption of Children Act. Upon applying to adopt a child, all information about the birth parent(s), the child and the adoptive parents were presented to the District Court in the form of an affidavit. A District Judge would hear the case and approve or decline the adoption. These hearings were all public and any person who was affected by the adoption could be present (Griffith, 1981). Once the adoption was approved, the only amendment that could be made to the child's name was to hyphenate the adoptive surname after the birth surname (Griffith, 1981). Judges at this time did not have the authority to make any other changes (Newman, 2011).

This Act was to have no effect on the practice of whāngai, in fact, this customary practice continued to be recognised under the New Zealand Constitution Act 1852 (Griffith, 1997).

\section{Conclusion}

Māori and Pākehā had their own understandings of how to care for children. Māori practised whāngai, Pākehā understood "adoption" and institutional care. What occurred from 1840 to 1881 was a conflict of ideas about the temporary or permanent care of children who were not the biological children of the carers. Informal adoption was encouraged by the Crown government with the intervention of ordinances. The Destitute Persons Relief Ordinance of 1846 was introduced in part to cater for half-caste children and that encouraged European fathers to place their children in the custody of European families to gain a European education. The introduction of the "1867 Ordinance for Neglected and Criminal Children" established the Industrial and Reformatory Schools where children from dysfunctional families (according to the Crown) would be saved and raised as good citizens of society. Throughout this period the terms "adopt" and "adoption" had been used even though there was no adoption law at the time and these were terms that appeared to terrify the authorities as they saw them as a form of slavery. This concern was an important part of the debate in parliament when the 1881 Adoption of Infants Bill was in the process of becoming an act.

The government's main concern was the status of Pākehā and half-caste children. The lack of visibility that Māori held within the society of the time meant that Māori custom was mostly ignored. It was not until Māori ourselves started to notice that Pākehā were using whangai arrangements as a way to inherit Māori land that Māori adoptions were placed under the jurisdiction of Native Land Court. While this change and the widespread adoption and fostering by Pākehā of Māori children in the mid-20th century is not covered in this article, it is a site of ongoing research and discussion. Throughout this time, Māori, especially those who continued to live in their kāinga, continued, and continue the practice of whāngai.

Accepted 7 September 2020

Published 3 November 2020

\section{References}

Aginsky, B. W., \& Buck, T. R. H. (1940). Interacting forces in the Maori family. American Anthropologist, 42(2), 195-210.

Adoption Act 1955. Reprint as at 07 August 2020.

Amendment to the Neglected and Criminal Children's Act. (1870).

An Act to consolidate and amend certain enactments oft he General Assembly relating to the adoption of children. (1955). [Short title: Adoption Act 1955].

An Act to grant a Representative Constitution to the Colony of New Zealand. (1852). [Short title: New Zealand Constitution Act 1852]. 
An Act to Legalize the Adoption of Children. (1881). [Short title: The Adoption of Children Act, 1881].

An Act to Provide for the Care and Custody of Neglected and Criminal Children. (1867). [Short title: The Neglected and Criminal Children Act, 1867].

An Ordinance for the Support of Destitute Families and Illegitimate Children. (1846). [Short title: Destitute Persons, 1846].

Bradley, J. (1997). Kei konei tonu matou [We are still here]. In Adoption and Healing: Proceedings of the international conference on Adoption and Healing. Wellington, NZ: New Zealand Adoption Education and Healing Trust.

Caversham Industrial School. (1880). Report of Commission appointed to inquire into the working and management of. Retrieved from https://atojs.natlib.govt.nz/cgi-bin/ atojs? $a=d \& d=A J H R 1880-1.2 \cdot 2 \cdot 3.9$

Daily Southern Cross. (1843). The Euronesians, Or the Children of European and Native Parents. (Vol. I), 23, 23 September.

Daily Telegraph. (1889). Waipawa. Issue 5494, 05 April.

Else, A. (1991). A question of adoption: Closed stranger adoption in New Zealand 1944-1974. Bridget Williams Books.

Gillard-Glass, S., \& England, J. (2002). Adoption New Zealand: The never-ending story. Harper Collins Publishers.

Graham, G. (1948). Whangai tamariki. The Journal of the Polynesian Society, 57(3), 268-278.

Griffith, K. (1997). New Zealand adoption: History and practice, social and legal, 1840-1996: process and practice, special issues, records and access, Maori adoption, statutes and rules, bibliography, case law indexes. Author.

Griffith, K. (1981). Adoption: Procedure-Documentation Statistics, New Zealand 1881-1981 100 Years. Victoria University Press.

Hope, G. W. (1843). The Euronesians, or the children of European and native parents. The Southern Cross. (Vol. I), 23, 23 September.

Mead, S. M. (1997). Tamaiti whangai: The adopted child. In Landmarks, bridges and visions (pp. 204-212). Victoria University Press.

Metge, J. (1995). New growth from old: The whānau in the modern world. Victoria University Press.

Mikaere, A. (1994). Maori Women: Caught in the Contradictions of a Colonised Reality. Waikato Law Review Vol. 2. Retrieved from http://www.waikato.ac.nz/ law/wlr/1994/article6-mikaere.html.

Newman, E. (2011). A right to be Māori? Identity formation of Māori adoptees (Master's thesis). University of Otago, Dunedin.

New Zealand Herald. (1888). Untitled. (Vol. XXV), 9024, 10 April.

New Zealand Mail. (1882). Untitled. Issue 564, 25 November.

New Zealand Parliamentary Debates. (1881). (Vol. 39). Government Printer.

New Zealand Spectator and Cook Strait Guardian. (1852). On the causes of decay among the New Zealand Race. Preview of the report (Vol. VIII), 722, 26 May.

New Zealander. (1846). Legislative Council. (Vol. 2), 72, 17 October.
Otago Daily Times. (1888). Special Telegram: A Strange Application. Issue 8154, 11 April.

Otago Witness. (1888). Telegraphic Briefs. Issue 1899, 13 April.

Papakura, M. (1986). The old-time Maori. New Women's Press. Retrieved from http://www.nzetc.org/tm/scholarly/ tei-MakOldT-t1-body-d2.html

Report on Education. (1881). Industrial Schools and Orphanages (Papers Relating To). Retrieved from https:// atojs.natlib.govt.nz/cgi-bin/atojs?a=d\&d=AJHR1881-I.2.1. 6.9\&e=-------10--1------0--

Soanes, C., \& Stevenson, A. (Eds.). (2008). Concise Oxford English dictionary (11th ed.). Oxford University Press. [Original edition, 1911].

Tennant, M. (2007). The fabric of welfare: Voluntary organisations, government and welfare in New Zealand 1840-2005. Bridget Williams Books.

Te Rito, J. S. (2007). Whakapapa: A framework for understanding identity. MAI Review, 1-10. Retrieved from http://www.review.mai.ac.nz/mrindex/MR/article/ download/56/56-65-1-PB.pdf

Walker, P. (2001). The Fox boy: The story of an abducted child. London, UK: Bloomsbury Publishing.

Walker, S. (2001). The Maatua Whangai Programme o Otepoti: From a caregiver perspective (Master's thesis). University of Otago, Dunedin.

Wanganui Herald. (1877). (Vol. XII), 2972, 30 June.

Wellington Independent. (1869). Local and General News: Brutality Extraordinary. (Vol. XXIV), 2867, 27 July.

Williams, H. (1992). Dictionary of the Maori Language (5th ed.). Wellington, NZ: GP Publications.

Willis, A. (1901). Regulations under Section 50 of "The Native Land Claims Adjustment and Laws Amendment Act, 1901". The New Zealand Gazette, 12 December (Vol. 104. p. 2352) 